\title{
The path of craftsman spirit into the core competence training of higher vocational education
}

\section{Bo Wang}

Changjiang Polytechnic, Hubei Province, Wuhan City the People's Republic of China, 430074.

Scientific Research Project of Hubei Institute of Vocational and Technical Education in 2019. (Item No.ZJGA201915)

Research Project of China Vocational Education Association of Hubei Province in 2020 (Item No.HBZJ2020081)

Abstract: The teaching goal of higher vocational colleges is to cultivate outstanding skilled talents for social development, so that they not only have solid professional knowledge and skills, but also have good professional qualities. The former can be achieved through systematic learning, but the latter is more of a kind of exercise for students' thinking and behavior, which has certain difficulties in actual operation. Based on the above reasons, this article mainly analyzes the integration of "craftsman spirit" into the core competence of higher vocational education, hoping to cultivate and improve the professional quality of students and improve the quality of higher vocational education.

Keywords: Craftsman spirit; higher vocational education; core competence; training path

The so-called "craftsman spirit" is a kind of inherent professionalism, and its core content is the workers' unremitting pursuit of excellence in their own work, and strictly abide by their own professional ethics at work. This spiritual manifestation is the current higher vocational education in China. The missing part in. Therefore, based on years of experience in higher vocational education and teaching, the author analyzes the teaching reform measures to integrate the "craftsman spirit" into higher vocational education and teaching, so as to improve the quality of higher vocational education and cultivate more high-level professional skills that meet the needs of social development for the country Talent.

\section{The importance of integrating craftsmanship into higher vocational education}

First of all, the integration of "craftsmanship spirit" in higher vocational education can train students to have good professional qualities, help students improve their competitiveness in future work, and have a very good role in promoting students' future career development. Secondly, the main purpose of cultivating students to possess the "craftsman spirit" is to guide students to work steadily, strive for perfection in future work, and constantly improve their professional skills, and make unremitting efforts to build my country's independent professional brand. Finally, the integration of "craftsmanship spirit" education in higher vocational education can improve the effectiveness of student management, and build a good learning atmosphere within the school, and increase the enthusiasm of students and teachers for learning, which is important for the further development of China's higher vocational education. Very positive effect.

\section{Current status of core competence training in higher vocational education}

\subsection{Higher vocational students have limited professional cognition for the major they are studying}

Copyright (C) 2020 Bo Wang

doi: 10.18282/le.v9i5.1217

This is an open-access article distributed under the terms of the Creative Commons Attribution Non-Commercial License

(http://creativecommons.org/licenses/by-nc/4.0/), which permits unrestricted non-commercial use, distribution, and reproduction in any medium, provided the original work is properly cited. 
The students who enter vocational schools basically have a relatively poor foundation in cultural courses, and are not interested in continuing learning. Most of them have a passing mentality. They are also at a loss for their own future development. Few students have a better understanding of the future. Detailed planning, therefore, the choice of professional learning is left unchecked, and the employment goals are relatively vague, which makes students less motivated to learn, and the cultivation of professional quality becomes rootless.

\subsection{Teachers' professional ability is limited in higher vocational teaching}

The main goal of higher vocational teaching is to enable students to have solid professional skills and knowledge to meet their future employment needs after graduation. Therefore, in actual teaching, teachers should not only train students to have solid professional theoretical knowledge, but also train students' practical skills. Therefore, the requirements for teachers' professional level are more stringent. However, in actual teaching, most of the teachers in higher vocational schools have limited professional abilities and lack of practical experience. It is difficult to accurately grasp the needs of the industry to educate students, and the teaching effect is relatively low.

\subsection{The vocational quality education in higher vocational education has not yet formed a complete system}

In traditional higher vocational education, although the concept of quality education has been implemented for many years, the training and education of vocational quality is still not included in the teaching plan of higher vocational colleges, and the teaching characteristics of "emphasizing theory and neglecting quality" in traditional teaching are still In the continuous continuation, the teaching method of "craftsman spirit" is still advancing in continuous exploration, and a relatively complete professional quality teaching system has not been formed. If things go on like this, the educated students will be more impetuous in actual work, and cannot comfortably hone themselves in basic positions, so that there are very few really useful talents.

\section{Path analysis of the craftsman spirit into the core competence training of higher vocational education}

\subsection{Raise the requirements of higher vocational talents education and enhance the social status of vocational education}

First of all, higher vocational colleges should formulate higher standards of talent education requirements, starting from multiple perspectives such as management methods, service content, and talent training models, and further improve the talent training system of higher vocational colleges, and strive to do professional, Grasp the quality together. Second, the country should gradually improve the social status of higher vocational education, change people's prejudice against higher vocational education, and set up a large number of excellent vocational education examples. Finally, cultivate students' self-confidence in learning and use the "craftsman spirit" to encourage students to make extraordinary achievements in ordinary positions.

\subsection{Improve teachers' professional quality}

In order to better implement the "craftsman spirit" education, schools should improve the professional skills of teachers. First of all, improve the treatment of teachers and attract more professional teachers with "real materials" to join the job. Secondly, regularly carry out professional training for existing teachers, and provide corporate exchange internship opportunities to enhance teachers' actual work experience, so as to improve their own knowledge and learning, and avoid talking on paper. Finally, pay attention to the inheritance of technology in teaching, to encourage students to learn the working methods and attitudes of master craftsmen, so as to improve the practical ability of vocational students and form good professional qualities.

\subsection{Pay attention to the school-enterprise combination model, and promote the improvement of quality education through practice}

The school-enterprise cooperation model is a new teaching practice model, which can not only greatly reduce the investment in the school practice base, but also provide students with richer practice opportunities, and help students clarify their future employment choices after graduation. Establishing a comprehensive school-enterprise cooperation 
training platform is conducive to improving the professional quality training system, urging students to be familiar with the content of future work, prepare for work in advance, and cultivate the corresponding professional quality in actual work, so as to truly drive quality through practice The improvement of students will lay a good foundation for the future work of students.

\section{Concluding remarks}

In summary, it is very necessary to integrate the "craftsman spirit" into higher vocational education, but it is undeniable that the cultivation of "craftsman spirit" does not happen overnight. Schools need to improve teaching requirements, enhance teachers' professional ability, and be a good student The practice and training work, integrating teaching resources and gradually improving the related professional quality training system, promote the development of higher vocational education with the gain effect of "craftsman spirit", improve people's traditional concept of higher vocational education, and cultivate more high-level High-quality talents.

\section{References}

1. Wang Ruirong. Research on Integrating Craftsman Spirit into the Training Path of Skilled Talents in Higher Vocational Colleges[J]. Experimental Technology and Management, 2018, Zhejiang Province Philosophy and Social Science Planning Project (17NDJC148YB); 2016 Zhejiang Higher Education Classroom Teaching Reform Project (002): 152-154.

2. Qian Huanhuan. Research on the innovation of craftsmanship spirit into ideological and political education in higher vocational colleges[J]. Journal of Hubei Adult Education Institute, 2018, v.24; No.136(02):62-64.

3. Tao Hong, Shan Lina. Analysis of the status quo of the integration of craftsman spirit into the training of skilled talents in higher vocational colleges[J]. Higher Vocational Education Exploration, 2018(2). 106-112. 